\title{
SLOVENSKÉ MÚZEJNÍCTVO V MEDZIVOJNOVOM OBDOBÍ, MOŽNOSTI A VÝCHODISKÁ ROZVOJA
}

\section{ĹUBOŠ KAČÍREK - PAVOL TIŠLIAR}

\section{ABSTRAKT/ABSTRACT:}

Po vzniku Československej republiky na Slovensku prevažovali najmä spolkové múzeá, postavené zväčša na dobrovol'nej báze. Mnohé z nich zápasili s existenčnými problémami, bez finančného zabezpečenia, bez vhodných priestorov, ale tiež s chýbajúcou metodikou, čo sa často odrážalo v ich základných múzejných činnostiach. Príspevok sa zameria na prehlad fungovania slovenského múzejníctva v medzivojnovom období. Sleduje rozvíjanie múzeí založených pred rokom 1918, zakladanie nových, špecializovaných múzeí (Zemedelské múzeum v Bratislave, Banské múzeum Dionýza Štúra v Banskej Štiavnici, Židovské múzeum v Prešove), formovanie celonárodného múzea vlastivedného zamerania (Slovenské národné múzeum v Turčianskom Sv. Martine vs Slovenské vlastivedné múzeum v Bratislave) a ich vzájomné vzt̉ahy k Zväzu československých múzeí v kontexte budovania jednotnej múzejnej siete v ČSR, profesionalizácii pracovníkov múzeí a ochrane múzejných zbierok.

\section{Slovak museums in the interwar} period, possibilities and foundations of development

After the emergence of Czechoslovak Republic, Slovakia mainly had associational museums which were operated on a voluntary basis. Many of them encountered existential problems, having no financial means, suitable premises and appropriate methodical guidelines, which was often reflected in their basic museum activities. The paper provides an overview of museum life in Slovakia during the interwar period. It follows up the development of museums founded before 1918, establishment of new specialised museums (Agricultural Museum in Bratislava, Mining Museum of Dionýz Štúr in Banská Štiavnica, Jewish Museum in Prešov), formation of a nationwide museum of Slovak national history (Slovak National Museum in Turčiansky Svätý Martin vs. Slovak Museum of National History in Bratislava) and their relationship to the Union of Czechoslovak Museums in the context of development of a unified museum network in the Czechoslovak Republic, professionalisation of museum workers and protection of museum collections.

\section{KLÚČOVÉ SLOVÁ/KEYWORDS:}

slovenské múzeá - Svaz československých muzeímedzivojnové Slovensko - Slovak museums - Union of Czechoslovak Museums - interwar Slovakia

Vznik Československej republiky predstavoval pre rozvoj slovenskej kultúry skutočne výrazný medzník. Prejavilo sa to najvýraznejšie v oblastiach viazaných najmä na používanie slovenčiny vo verejnom živote, kedž̌e posledné decénia Rakúsko-Uhorska sa niesli
https://doi.org/10.5817/MuB2020-1-1

v znamení výraznejšej mad’arizácie. V mladom Československu sa však sprvu sústredila pozornost̉ najmä na budovanie základov štátu a jeho hospodársku stabilizáciu. Oblast' kultúry sa tak spočiatku dostala do ústrania. Navyše múzejníctvo patrilo v kultúrnej sfére skôr $\mathrm{k}$ vedlajším a okrajovým oblastiam, ktoré ustupovali tzv. vyššej kultúre (divadlo, hudba, umenie a literatúra). Práve z tohto hladiska je potrebné hodnotit aj predpoklady a možnosti rozvoja slovenského múzejníctva $\mathrm{v}$ tomto období. Nie, že by sa podmienky pre jeho rozvoj v novom štátnom útvare zhoršili, ale významne do tohto procesu zasiahla skutočnost', že sa múzeá jednoducho nestali v medzivojnovom období preferovanými kultúrnymi inštitúciami, ktorým by bola venovaná dostatočná pozornoste zo strany štátu. ${ }^{1}$ Nešlo pritom len o vztah kultúrnej politiky a múzeí, ale rovnako dôležitý bol aj nezáujem verejnosti o múzeá. Múzeá a ich činnost v medzivojnovom období na Slovensku bola skôr výsledkom aktivity jednotlivcov, nadšencov, zberatelov, ktorí budovali ich zbierky. Verejnost' si len postupne vytvárala k týmto inštitúciám

\footnotetext{
1 Problémom kultúrnej politiky a múzeí, múzeí a verejnosti na Slovensku sme sa podrobnejšie venovali v príspevku: TIŠLIAR, Pavol, Jan DOLÁK a Luboš KAČÍREK. Changes in cultural strategy and cultural policies in Slovakia in the 20th century and at the beginning of the 21st century: museums and other memorial institutions in a socio-political context. Bylye gody, 2018, roč. 48 č. 2, s. 709-718; KAČíREK, Luboš. Edičná činnost' múzeí v druhej polovici 19. a prvej polovici 20. storočia. Muzeológia a kultúrne dedičstvo, 2017, roč. 5 , č. 1 , s. 47.
} 
vztah a spočiatku im nevenovala vel'kú pozornosté.

\section{Vznik ČSR a pamätové inštitúcie na Slovensku}

Rozpadom Rakúsko-Uhorska došlo k prerušeniu kontaktov medzi ústrednými pamätovými a pamiatkovými inštitúciami, sústredenými v Budapešti ako v hlavnom meste Uhorska, a slovenským prostredím. Týkalo sa to stavebných a umeleckohistorických pamiatok, knižníc, archívov, ale aj múzeí, na ktoré v poslednej tretine 19. storočia dozeral a odporúčal subvencovanie inšpektor knižníc a múzeí. ${ }^{2}$ Bolo tak potrebné vytvorit celú oblast ochrany a správy kultúrneho dedičstva na území Slovenska znova. Recepčnou normu bol do nového štátneho útvaru recipovaný právny systém bývalej Rakúsko-uhorskej monarchie, ktorý znamenal kontinuitu právneho dualizmu. ${ }^{3}$ Na Slovensku tak ostal v platnosti zákonný článok o zachovaní (ochrane) pamiatok z roku 1881, ktorý však múzeá vôbec nespomínal. ${ }^{4}$

Už tesne po vzniku ČSR bola na Slovensku vyhlásená vojenská diktatúra a výnimočný stav, ktorý sa týkal aj ochrany pamiatok, a to predovšetkým zákazom ich vývozu v celorepublikovom meradle. ${ }^{5}$ Treba však zdôraznit, že zákaz vývozu sa nedotkol súkromných zbierok či súkromných archívov, čo

2 Inšpektor vykonával svoju činnoste na základe štatútu z roku 1907. Archív Pamiatkového úradu SR v Bratislave (d’alej APÚ SR), fond Štátny inšpektorát archívov a knižníc na Slovensku (d’alej fond ŠIAK), škat. č. 1, sign. č. 390/1922; FRAKNOI, Vilmos. Visszatekintés A muzeumok és kőnyvtárak országos tanácsa és föfelügyelösége egy évtized munkásságára (1898-1907). Budapest: Stephaneum Nyomda r.t., 1908, s. 1-4.

3 Z. č. 11/1918 Sb. z. a n.

4 Zák. čl. XXXIX:1881. Bližšie aj: ORIŠKO, Štefan a Peter BUDAY. Pramene $k$ umelecko-historickému bádaniu a ochrane pamiatok na Slovensku

(1846-1918). Bratislava: Stimul, 2017, s. 8-47.

5 Z. č. 13/1918 Sb. z. a n. vzhl’adom k vysokým migračným pohybom po rozpade monarchie hlavne smerom zo Slovenska do Mad’arska znamenalo aj vyvezenie rozsiahlych súborov umeleckých, výtvarných diel a historických artefaktov. K najznámejším prípadom patrí napríklad vývoz archívu a zariadenia Baníckej a lesníckej akadémie v Banskej Štiavnici. Z niektorých múzeí na území Slovenska, napríklad z trenčianskeho múzea, na prelome rokov 1918/19196 bola rovnako vyvezená do Mad’arska čast’ zbierok. Aj následné mierové rokovania, ktoré sa týkali aj problematiky delenia kultúrneho dedičstva bývalej monarchie, ostali nenaplnené. Mnoho artefaktov a písomností, ktoré pochádzali z územia Slovenska a dotýkali sa jeho dejín, tak dodnes ostali v mad’arských pamätových inštitúciách.7

\section{V literatúre sa spomína rôzny} počet existujúcich múzeí na Slovensku do vzniku ČSR. Prevažne sa uvádza počet 24 múzeí, resp. múzejných zbierok ${ }^{8}$ Tento

6 JURKOVIČ, Miloš. Slovenské múzeá. Bratislava: Slovenský fond výtvarných umení, 1945, s. 123-125.

7 Pozri bližšie napr. CIULISOVÁ, Ingrid. Osudy pamiatok na Slovensku 1919-1949. Poprad: KUBKO GORAL, 1994.

8 Zoznam uvádzaných múzeí v abecednom poradí podla lokalít: Mestské múzeum v Banskej Bystrici (1888), Mestské múzeum s knižnicou v Banskej Štiavnici (1900), Šarišské župné múzeum v Bardejove (1905), Mestské múzeum (1868) a Múzeum spolku lekárov a prírodovedcov v Bratislave (1854), múzeum v Kežmarku (1873), múzeum Jókaiho kultúrneho spolku v Komárne

(1886), Hornouhorské štátne Rákócziho múzeum v Košiciach (1872), Mestské múzeum v Kremnici (1890), Spišské múzeum v Levoči (1884),

prírodovedná zbierka Jána Volka-Starohorského

v Liptovskom Svätom Mikuláši (1904), Múzeum Muzeálnej slovenskej spoločnosti v Turčianskom Svätom Martine (1893), Múzeum Oravského komposesorátu v Oravskom Podzámku (1868), Župné múzeum v Nitre (1896), Múzeum Uhorského karpatského spolku v Poprade (1883), Župné gemerské múzeum v Rimavskej Sobote (1882), Banícke múzeum v Rožňave (1902), Múzeum Liptovskej múzejnej spoločnosti v Ružomberku (1912), Blahovo múzeum v Skalici (1905), Župné múzeum v Šahách (1896), Múzeum Trenčianskej župnej múzejnej spoločnosti v Trenčíne (1877), historická zbierka pri mestskej knižnici v Trnave, Tatranské múzeum vo Vel'kej pri Poprade (1882) a múzeum v Zlatých Moravciach (1896). Bližšie problém azda najpresnejšie aj vystihuje situáciu, v akom sa slovenské múzejníctvo nachádzalo. Neexistencia centrálneho registra či evidencie, ale aj absentujúcej legislatívnej úpravy, ktorá by jasne zadefinovala múzeum ako inštitúciu, poukazuje na značný nezáujem štátnej kultúrnej politiky o túto oblast'. Kultúrna politika sa v tomto období formovala, ako sme už spomenuli, predovšetkým s ohladom na tzv. „vyššiu“ kultúru. Platilo to pre celé Československo, pretože s presnejšou evidenciou a údajom o počte múzeí po vzniku ČSR sa nestretneme ani v Česku. Slovensko však vstupovalo do ČSR s nepomerne nižším počtom múzejných zariadení ako západná čast’ novej republiky, kde bol ich počet odhadom približne 10-násobne vyšší.

Správa a riadenie múzeí patrilo do agendy ministerstva školstva (MŠA), kam boli zaradené spoločne s archívmi, zberatel'stvom, obchodom so starožitnostami, ale tiež ochranou prírodných a historických pamiatok, pamiatkových zákonov, súpismi, pamiatkovým archívom, fotometrickým ústavom a inventármi štátneho umeleckého majetku. Ministerstvo školstva získalo kompetencie bývalej viedenskej Ústrednej komisie pre zachovanie pamiatok a štátneho úradu pre pamiatky bývalej rakúskej časti monarchie. V Prahe a Brne vznikol Štátny pamiatkový úrad. ${ }^{9} \mathrm{Na}$ Slovensku pôsobil v rámci úradu Ministra

napríklad: BOHUŠ, Ivan. Slovenské múzeá a prvá svetová vojna. Múzeum, 1958, roč. 5, č. 2, s. 76-77; HERČKO, Ivan a kol. Dejiny múzejnej kultúry na Slovensku. Banská Bystrica: Univerzita Mateja Bela, 2009, s. 113; MRUŠKOVIČ, Štefan, Jolana DARULOVÁ a Štefan KOLLÁR. Múzejníctvo, muzeológia a kultúrne dedičstvo. Banská Bystrica: Univerzita Mateja Bela v Banskej Bystrici, 2005, s. 105; PALÁRIK, Miroslav. Zväz slovenských múzeí v období slovenského štátu 1939-1945. Nitra: Univerzita Konštantína Filozofa v Nitre, 2011, s. 18. 9 DVOŘÁK, Jan. Vývoj ideí a organisace ochrany památek. In PLACHT, Otto a František HAVELKA (eds.). Příručka školské a osvětové správy: Pro potrebu služby školských a osvětových úřadů 
ČSR s plnou mocou pre správu Slovenska sprvu Vládny komisariát pre zachovanie umeleckých pamiatok na Slovensku, ktorý od roku $1919^{10}$ oficiálne dozeral aj nad agendou múzejníctva. Z hladiska právomoci komisariátu sem patrila ochrana výtvarných umeleckých, historických, ludových a prírodných pamiatok, ale tiež „ochrana svojrázu kraja a domoviny" na Slovensku. Komisariát dostal právomoci bývalej uhorskej pamiatkovej komisie. Príslušnost agend odboru ochrany pamiatok bola komplexne a taxatívne vymedzená. ${ }^{11}$ Okrem pomerne rozsiahlej pamiatkovej oblasti mal komisariát dohliadat aj na vykonávanie predpisov k zabráneniu vývozu pamiatok a obchodovaniu so starožitnostami. Patrili mu aj právomoci bývalého uhorského inšpektora múzeí a knižníc, ktoré sa týkali dozoru nad múzeami. ${ }^{12}$ Pre činnost' vládneho komisariátu, ale aj jeho nástupcu Štátny referát na ochranu pamiatok (od r. 1922 bol súčastou Inšpektorátu knižníc a archívov na Slovensku) ${ }^{13}$ bolo príznačné, že na jednej strane mala rozsiahlu agendu pamiatok a rôznych oblastí

a orgánů. Praha: Státní nakladatelství, 1934, s. 1620 .

10 Podrobne pozri TIŠLIAR, Pavol. Formovanie ochrany pamiatok na Slovensku po vzniku Československej republiky. Vládny komisariát na ochranu pamiatok na Slovensku a Štátny inšpektorát archívov a knižníc na Slovensku. In GRESCHOVÁ, Eva. Stretnutie seniorov štátnej ochrany prírody na Slovensku. Liptovský Mikuláš: Slovenské múzeum ochrany prírody a jaskyniarstva, 2019, s. 5-19.

11 NESVADBÍKOVÁ, Jiřina. K vývoji památkové péče na území Československa. 3. svazek: Výběr autentických dokumentů 1918-1958. Praha: Státní pedagogické nakladatelství, 1983, s. 228 a n.

12 NESVADBÍKOVÁ, Jiřina. $K$ vývoji památkové péče na území Československa. 3. svazek: Výběr autentických dokumentů 1918-1958. Praha: Státn pedagogické nakladatelství, 1983, s. 228 a n., §4 nariadenia MPS č. 155/1919/8380-pres.

13 Národní archiv České republiky v Prahe (d’alej NAČR), fond Ministerstvo školství (d'alej fond $M S ̌ A)$, kart. 3126, sign. č. 1291/24. Podrobnejšie o legislatíve v 20. rokoch pozri: Zákony a nariadenia na ochranu pamiatok historických, pravekých a prírodných na Slovensku. 3. vyd. Bratislava: Nákladom Štátneho referátu - tlačou Slovenskej kníhtlačiarne, 1924 - kapitola Ochrana movitých pamiatok, s. 4-9. kultúrneho a prírodného dedičstva, ale na druhej strane výrazný nedostatok personálu. To $\mathrm{v}$ praxi znamenalo, že sa aj agende múzeí nevenovala dostatočná pozornost́. A to aj napriek tomu, že Ján Hofman už od roku 1922 prednášal múzejníctvo na novoutvorenej bratislavskej univerzite. ${ }^{14}$

Kompetencie komisariátu, resp. pamiatkového referátu sa v praxi mohli vztahovat’ výlučne na odporúčania a rozdelovanie subvencií múzeám na Slovensku. ${ }^{15}$ Tie boli nízke a pohybovali sa vo výškach od niekol'ko sto korún do niekol'ko tisíc. Navyše neboli poskytované plošne pre všetky múzeá na Slovensku. ${ }^{16}$ Týkali sa len múzeí, ktoré boli členmi zväzu múzeí.

\section{Ako sme už naznačili,}

Československá republika zdedila roztrieštené slovenské múzejníctvo, ktoré nebolo vôbec organizované, nikým a ničím. Fungovalo úplne živelne. Najväččím problémom $\mathrm{v}$ tomto ohlade bola absencia právneho ukotvenia múzea ako inštitúcie. Chýbalo vymedzenie jeho postavenia, úloh, kompetencií, vzájomného vztahu k štátu a verejnej správe. Hoci boli počas medzivojnového obdobia viaceré pokusy zmenit tento stav a snahu nemožno upriet', počas 1. pol. 20. storočia sa to vyriešit nepodarilo. Okrem toho živelnost a nesystémovost' zvýrazňoval aj

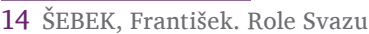
československých muzeí ve vývoji českého (československého) muzejnictví. In HUPKO, Daniel a Luděk BENEŠ (eds.). Dokumentácia „osmičkových" výročí $v$ slovenských a českých múzeách. Rok 1918 a tie ostatné. Banská Bystrica: Zväz múzeí na Slovensku, 2018, s. 136.

15 NAČR, fond MŠA, kart. č. 3251, sign. č. 151426/31.

16 NAČR, fond $M \check{S}$ A, kart. č. 3251, napr. v roku 1936 bolo subvencovaných 14 múzeí v sume od 1000-3500.- Kč., pozri bližšie PALÁRIK, Miroslav. Múzejná siet na Slovensku v období I. Československej republiky - predstavy a realita. In HUPKO, Daniel a Luděk BENEŠ (eds.).

Dokumentácia „osmičkových“ výročí v slovenských a českých múzeách. Rok 1918 a tie ostatné. Banská Bystrica: Zväz múzeí na Slovensku, 2018, s. $100-101$.
}

charakter zriad’ovatel'ov múzeí. Prevládali tu hlavne spolkové múzeá, udržiavané svojpomocne spolkami, členskými prostriedkami, rôznymi darmi a drobnými dotáciami. ${ }^{17}$ Tie však neumožňovali akúkolvek profesionalizáciu múzeí. Práve nedostatok finančných prostriedkov sa výrazne odrážal jednak v múzejných činnostiach a možnostiach ich vykonávat', ale tiež v mnohých prípadoch neumožňoval rozvinút sa vôbec do podoby štandardného múzea $s$ vlastnou prezentačnou činnostou. Dobrovolná báza, na ktorej bola postavená správa a spracovanie zbierok, ked' kustódov robili často najmä miestni zanietení učitelia, neumožňovala vidinu akéhokolvek výraznejšieho rozvoja či lepšej budúcnosti. K týmto možnostiam sa slovenské múzeá dostali prakticky až na začiatku druhej polovice 20. storočia v súvislosti s postupným poštátňovaním múzeí a získaním pravidelného a plánovitého financovania. ${ }^{18}$

\section{Zväz československých múzeí a slovenské múzeá}

Múzeá, resp. ich agenda, boli organizačne začlenené pod MŠA v Prahe. To ale neznamenalo, že tomuto ministerstvu podliehali. Na Slovensku v medzivojnovom období fungovali štyri štátne múzeá (Východoslovenské múzeum v Košiciach, Štátne banské múzeum Dionýza Štúra v Banskej Štiavnici, Štátne múzeum v Nitre a Štátne Šarišské múzeum v Bardejove) $\mathrm{s}$ verejným rozpočtom. $\mathrm{Z}$ nich len banskoštiavnické vzniklo v medzivojnovom období. Ostatné boli ešte pozostatkom

\footnotetext{
17 DVOŘÁK, Jan. Vývoj ideí a organisace ochrany památek. In PLACHT, Otto a František HAVELKA (eds.). Př́ručka školské a osvětové správy: Pro potřebu služby školských a osvětových úřadů a orgánů. Praha: Státní nakladatelství, 1934, s. 1705.

18 MRUŠKOVIČ, Štefan, Jolana DARULOVÁ a Štefan KOLLÁR. Múzejníctvo, muzeológia a kultúrne dedičstvo. Banská Bystrica: Univerzita Mateja Bela v Banskej Bystrici, 2005, s. 78-79.
} 
uhorskej správy múzeí, ktoré Československo zdedilo. $\mathrm{Na}$ zvyšné múzeá mal štát minimálny dosah a jeho opatrenia mali skôr odporúčajúci charakter, ked’že ich zriad'ovatel'mi boli v drvivej väčšine spolky, župy, mestá, alebo mali súkromný charakter. Je otázne, či štátne subvencie, ktoré tieto múzeá dostávali, možno označit za „účinnú páku“, ktorou by bolo možné nejakým spôsobom priamo ovplyvňovat, alebo dokonca účinne riadit kultúrnu politiku v oblasti slovenského múzejníctva. Na ministerstve sa síce vytvoril múzejný odbor na čele so Zdeňkom Wirthom, ktorý ale $\mathrm{v}$ praxi nemal na slovenské múzeá zo spomenutých dôvodov dosah. Len o niečo väčší dosah mal novozriadený Svaz československých muzeí vlastivědných (d’alej len Zväz), založený 28. septembra 1919, ${ }^{19}$ ktorý sa postupne začal podielat na odporúčaniach pri rozdelovaní štátnych dotácií aj slovenským múzeám. Zväz múzeí sa teda stal akýmsi prostredníkom medzi múzeami a ministerstvom školstva. Jeho význam však nebol len sprostredkujúci. Snahou Zväzu bolo jednotne usmerňovat živelné československé múzejníctvo, živelnú a neorganizovanú múzejnú činnosté. Vznikali napríklad snahy o zjednotenie evidencie a katalogizácie zbierkových predmetov. Zväz sa tiež angažoval v poradenskej činnosti múzeám a v snahe dovzdelávat pracovníkov. $\mathrm{V}$ jeho vedení stála volená múzejná rada a predsedníctvo. ${ }^{20} \mathrm{~V}$ roku 1937 bola dozorná činnost̉ Zväzu prenesená na novovytvorené

\footnotetext{
19 ŠEBEK, František. Role Svazu
}

československých muzeí ve vývoji českého (československého) muzejnictví. In HUPKO, Daniel a Luděk BENES (eds.). Dokumentácia „osmičkových" výročí v slovenských a českých múzeách. Rok 1918 a tie ostatné. Banská Bystrica: Zväz múzeí na Slovensku, 2018, s. 135-138.

20 Archiv Národního muzea v Prahe (d’alej ANM), fond Svaz československých muzeí (d'alej fond

$S C ̌ S M$ ), kart. 1, bez sign., stanovy zväzu. funkcie múzejných inšpektorov. ${ }^{21}$ Na Slovensku v tejto funkcii pôsobil Josef Polák, riaditel' košického múzea. ${ }^{22}$

Ani v prípade zväzu múzeí určite nemožno tvrdit, že ním bolo slovenské múzejníctvo „riadené či formované, alebo pod jeho vplyvom“. ${ }^{23}$ Zväz bol totiž záujmovou, profesijnou organizáciou, ktorej členstvo stálo len na dobrovolných základoch. Členmi Zväzu teda nemuseli a ani zdaleka neboli všetky slovenské múzeá. Väčšina existujúcich slovenských múzeí dosiahla členstvo až na konci medzivojnového obdobia. ${ }^{24}$ V roku 1925 bolo členom Zväzu len 12 slovenských múzeí, aj to nie všetky najväčšie. Príkladom toho je martinské Múzeum, jedno z najvýznamnejších na Slovensku, ktoré sa stalo členom až v roku 1928. ${ }^{25}$ Ešte v roku 1935 to bolo len 14 múzeí. Teda záujem o členstvo bol iba čiastočný. Do roku 1938 sa stalo členom Zväzu d’alších 8 múzeí, teda celkovo bolo $22 \mathrm{z}$ približne 40 slovenských múzeí. ${ }^{26}$ Už z uvedeného je tak zrejmé, že vplyv Zväzu na formovanie slovenského

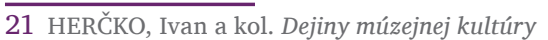
na Slovensku. Banská Bystrica: Univerzita Mateja Bela, 2009, s. 122.

22 KIRSCH, Otakar. (Po)zapomenutí nositelé paměti: Německé muzejnictví na Moravě. Brno: Paido, 2014, s. 86.

23 MRUŠKOVIČ, Štefan, Jolana DARULOVÁ a Štefan KOLLÁR. Múzejníctvo, muzeológia a kultúrne dedičstvo. Banská Bystrica: Univerzita Mateja Bela v Banskej Bystrici, 2005, s. 68.

24 PALÁRIK, Miroslav. Zväz slovenských múzeí v období slovenského štátu 1939-1945. Nitra: Univerzita Konštantína Filozofa v Nitre, 2011, s. 17-18.

25 HERČKO, Ivan a kol. Dejiny múzejnej kultúry na Slovensku. Banská Bystrica: Univerzita Mateja Bela, 2009, s. 116-117. Zaujímavé pritom je, že priamo pre zástupcu martinského Múzea bolo na zjazde v roku 1920 v Brne vyhradené miesto podpredsedu múzejnej rady zväzu. Pozri bližšie zápisnicu z 26. 9. 1920. ANM, fond SČSM, kart. 1, sign. č. $72 / 21$.

26 PALÁRIK, Miroslav. Zväz slovenských múzeí v období slovenského štátu 1939-1945. Nitra: Univerzita Konštantína Filozofa v Nitre, 2011, s. 17. múzejníctva bol značne obmedzený. O členstvo mali, podobne ako v Česku, ${ }^{27}$ len v minimálnej miere záujem múzeá riadené príslušníkmi menšín (nemecké na Spiši, ${ }^{28}$ mad’arské na južnom Slovensku). Záujem o členstvo vo Zväze mali hlavne tie múzeá, ktoré sa usilovali o získanie finančného príspevku od štátu. Zväz na Slovensku odporúčal, v spolupráci so Štátnym referátom na ochranu pamiatok, výšku dotácií pre jednotlivé múzeá. Vychádzal z českého modelu a usiloval sa o jednotný systém ich správy, čo bol hlavný kameň úrazu najmä pre múzeum spravované Muzeálnou slovenskou spoločnostou v Martine.

Po prijatí krajinského zriadenia v roku 1928 zasielal pamiatkový referát zoznam múzeí navrhovaných na udelenie dotácie predsedníctvu Zväzu, ktoré ho po schválení zasielalo Krajinskému úradu v Bratislave. ${ }^{29}$ Tieto subvencie sa pohybovali od symbolických, až po naozaj výrazné čiastky. ${ }^{30}$ Napríklad v roku 1931 Karpatské múzeum v Poprade dostalo dotáciu vo výške 600 korún, vzhl’adom na hospodársku krízu bola na rok 1932 táto suma znížená na 500 korún. Zväz však v rámci úsporných opatrení túto sumu ešte znížil na 450 korún, ale ministerstvo napokon udelilo

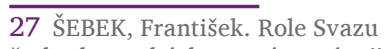
československých muzeí ve vývoji českého (československého) muzejnictví. In HUPKO, Daniel a Luděk BENEŠ (eds.). Dokumentácia „osmičkových" výročí v slovenských a českých múzeách. Rok 1918 a tie ostatné. Banská Bystrica: Zväz múzeí na Slovensku, 2018, s. 136.

28 Nemecké múzejníctvo malo v ČSR vytvorený vlastný zväz - Verband der deutschen Museen für Heimatkunde in der Tschechoslowakischen Republik (Zväz nemeckých múzeí pre vlastivedu v Československej republike). Pozri bližšie KIRSCH, Otakar. (Po)zapomenutí nositelé paměti: Německé muzejnictví na Moravě. Brno: Paido, 2014, s. $70 \mathrm{a} \mathrm{n.}$

29 PALÁRIK, Miroslav. Zväz slovenských múzeí v období slovenského štátu 1939-1945. Nitra: Univerzita Konštantína Filozofa v Nitre, 2011, s. 19.

30 Niekol'ko príkladov je uvedených aj v texte nižšie. 
múzeu len 200 korún. ${ }^{31}$ Naproti nemu Župné múzeum v Nitre dostalo na rok 1935 finančnú podporu 3-tisíc korún, z nich 2400 tvoril ročný plat kustóda. Zároveň Krajinský výbor v roku 1934 odsúhlasil múzeu dotáciu 10-tisíc korún na zakúpenie obrazu Knieža Pribina so synom Kocelom od maliara Maxa Schurmanna ako „trvalú pamiatku na 1100 ročné jubileum postavenia prvého krestanského chrámu $v$ Československu v Nitre ". ${ }^{32}$ Išlo však o štátne múzeum, teda priamo dotované rozpočtom.

Múzejné zjazdy Zväzu sa konali každoročne a postupne v Čechách, na Morave a Sliezsku a potom na Slovensku. Charakteristické pre ne bol bohatý poznávací, ale najmä prednáškový program, zameraný predovšetkým na oblast ochrany a správy pamiatok, dejín, archeologických vykopávok a samozrejme aj praktickej múzejnej činnosti. Na Slovensku sa prvý zjazd konal 3.-6. augusta 1922 v Bratislave. ${ }^{33}$ Prednášalo sa tu napríklad o organizácii slovenského múzejníctva (J. Hofman). Priestor dostalo aj predstavovanie vybraných slovenských múzeí, ako napríklad Liptovského múzea v Ružomberku (F. Houdek) a Tatranského múzea vo Vel'kej (E. Daitsch). Tohto, ale aj neskorších zjazdov, ktoré sa konali na Slovensku, v Martine (3.-4. júla 1927), ${ }^{34}$ Bratislave (8.-9. júna 1930), ${ }^{35}$ slovenských banských mestách - Banská Bystrica, Banská Štiavnica a Kremnica (2.-6. júla 1933) 36 a napokon na východe Slovenska -

31 NAČR, fond MŠA, kart. č. 6269. Poprad museum, udělení krajinské podpory, 1932-1933.

32 NAČR, fond $M \check{S} A$, kart. č. 3266. Nitra. Museum, 1934.

33 ANM, fond SČSM, kart. 1, bez sign.

34 ANM, fond SČSM, kart. 1, bez sign.

35 ANM, fond SČSM, kart. 1, bez sign. a J. G. Sjazd československých muzeí v Bratislave. In

ČMSS, 1930, roč. 22, s. 48-50

36 ANM, fond SČSM, kart. 1, bez sign.
Levoča, Košice (3.-9. júla 1936) ${ }^{37}$

a Podkarpatskej Rusi, sa

zúčastňovali početnejšie aj

zástupcovia viacerých slovenských

múzeí. No zjazdy konané

v západnej časti republiky bývali

zo slovenskej strany zastúpené

len vel'mi skromne. Múzejné

zjazdy mali pre slovenské múzeá

praktický význam. Podporovali

aktivitu a činnoste múzeí a hlavne

ich spoločenskú prezentáciu.

Účast̉ slovenských múzeí vo Zväze znamenala okrem iného aj to, že sa v slovenských múzeách, dokonca aj v tých, ktoré neboli členom Zväzu, postupne zaviedli jednotlivé tlačivá pre evidenciu zbierok a múzejní pracovníci sa mohli zúčastňovat na rôznych odborných kurzoch, školeniach a iných vzdelávacích profesijných podujatiach pripravovaných Zväzom. ${ }^{38}$

\section{Rozvoj múzejnej siete na Slovensku v medzivojnovom období}

Problémom medzivojnového múzejníctva na Slovensku je hlavne nedostatočná objasnenost̉ jeho celkového historického vývoja. V súčasnosti máme spracované zväčša len dejiny vybraných múzeí, aj to neúplne. Na Slovensku absentuje práca syntézneho charakteru dejín múzejníctva a v literatúre sa často opakujú, v mnohých ohladoch aj prežité názory, stereotypy či rôzne romantické predstavy, glorifikácia a mystifikácia jednotlivých osobností, ale aj úloh, významu a postavenia martinského Múzea, Muzeálnej slovenskej spoločnosti a ich prínos $\mathrm{v}$ celkovom progrese rozvoja kultúry a dokonca akejsi vedúcej úlohy a riadenia slovenského múzejníctva. $\mathrm{V}$ istom

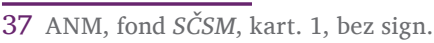

38 Bližšie: LALKOVIČ, Marcel. Zväz československých múzeí a jeho prínos na formovaní slovenského múzejníctva. In Zborník SNM - Etnografia 44, 2003, s. 91-119; PALÁRIK, Miroslav. Zväz slovenských múzeí v období slovenského štátu 1939-1945. Nitra: Univerzita Konštantína Filozofa v Nitre, 2011, s. 15-31.
}

zmysle sa podobne možno stretnút aj s názormi na zväz múzeí a jeho vel'kom vplyve na rozvoji slovenského múzejníctva.

Ešte v roku 1934 Jan Dvořák konštatoval, že neexistuje žiadny oficiálny zoznam múzeí v Československu. ${ }^{39} \mathrm{Na}$ Slovensku $\mathrm{v}$ tomto čase napočítal, okrem dvoch spomínaných štátnych (Košice, zal. 1872, a Banská Štiavnica, zal. 1927), až 49 d’alších (medzi mini boli v správe štátu aj Štátne múzeum v Nitre a Štátne Šarišské múzeum v Bardejove ${ }^{40}$ ), „ostatných" múzeí, teda múzeí súkromných, spolkových, mestských/obecných. ${ }^{41}$ Mnohé $\mathrm{z}$ nich však mali len úroveň zbierok, kde by sme zrejme ani priamo nemali hovorit o múzeách. Zaradil sem napríklad aj kláštorné zbierky v Hronskom Beňadiku a Skalici. Prekvapujúca je informácia o Múzeu odboja v Bratislave, ${ }^{42}$ v Nitrianskom Pravne (Deutch-Proben) a Slovenských (resp. Balážskych) Ďarmotách, o ktorých nemáme d’alšie informácie. Ďalšie „múzeá“ zasa fungovali skôr ako „sklady“, depozitáre bez sprístupnenia svojich zbierok a nevyvíjali takmer žiadnu činnost', resp. ich múzejná činnost̉ mala skôr symbolický

39 DVOŘÁK, Jan. Vývoj ideí a organisace ochrany památek. In PLACHT, Otto a František HAVELKA (eds.). Př́ručka školské a osvětové správy: Pro potřebu služby školských a osvětových úr̆adů a orgánů. Praha: Státní nakladatelství, 1934, s. 1695

40 Šarišské múzeum dostávalo v 30. rokoch ročne na plat správcu a zriadenca 14-18 tis. .- Kč dotáciu. Na chod a režijné náklady d’alšie približne 20-tis. .- Kč. NAČR, fond MŠA, kart. 3251, sign. č. 84095/36, rovnako aj v 20. rokoch s celkovou dotáciou do 28 tis. Kč. NAČR, fond $M S ̌ A$, kart. 3250, sign. č. 150192/27.

41 DVOŘÁK, Jan. Vývoj ideí a organisace ochrany památek. In PLACHT, Otto a František HAVELKA (eds.). Př́ručka školské a osvětové správy: Pro potřebu služby školských a osvětových úřadi̊ a orgánů. Praha: Státní nakladatelství, 1934, S. 1698-1699.

42 Je otázne, či nešlo o „Múzeum oslobodeného Slovenska“, ktoré v roku 1920 navrhoval zriadit v Bratislave Antonín Václavík v Grasalkovičovom paláci. NAČR, fond $M S \check{A}$, kart. 3252, sign.

č. $22151 / 20$. 
charakter. Je potom otázne, či takúto inštitúciu možno zaradit medzi múzeá, alebo ju evidovat len ako neverejnú zbierku súkromného charakteru. Absencia múzejnej legislatívy totiž umožňovala svojvol'ne vytvorit a pomenovat’ múzeom zbierku bez nejakej registrácie, bez konkrétnych a stanovených podmienok, teda živelne.

V medzivojnovom období postupne vznikali d’alšie múzeá, niektoré však aj zanikli. Na konci tohto obdobia tak možno predpokladat približne do 40 múzejných inštitúcií na Slovensku. ${ }^{43}$ Dôvody zániku niektorých múzeí možno hladat' predovšetkým $v$ spomínanom nedostatku finančných prostriedkov. Mnohé múzeá živorili a často, napríklad dlhé roky nemohli verejnosti sprístupnit’ nazhromaždené múzejné zbierky, pretože nemali k tomuto účelu vhodné priestory, budovy.

\section{Múzeá na Slovensku v medzivojnovom období}

Hlavnou reprezentantkou národnej línie slovenského múzejníctva a symbolom slovenskej národnej identity bolo Múzeum - neskôr s názvom Slovenské národné múzeum - spravované Muzeálnou slovenskou spoločnostou (d’alej MSS) v Turčianskom Svätom Martine. Po počiatočnej stagnácii na začiatku 20. rokov nabrala MSS od roku 1927 „druhý dych“, odkedy sa začal zvyšovat’ počet členov MSS a rozširovala sa jej vedeckovýskumná a zberatel'ská činnost'. Víziou MSS bolo vybudovat’ celonárodné múzeum ako centrum

43 PALÁRIK, Miroslav. Zväz slovenských múzeí v období slovenského štátu 1939-1945. Nitra: Univerzita Konštantína Filozofa v Nitre, 2011, s. 17; tiež PALÁRIK, Miroslav. Múzejná sieṫ na Slovensku v období I. Československej republiky predstavy a realita. In HUPKO, Daniel a Luděk BENEŠ (eds.). Dokumentácia „osmičkových“ výročí v slovenských a českých múzeách. Rok 1918 a tie ostatné. Banská Bystrica: Zväz múzeí na Slovensku, 2018, s. 87. slovenského vedeckého bádania a konkurovat́ rozmáhajúcemu sa vedeckému bádaniu v Bratislave. ${ }^{44}$

\section{V medzivojnovom období} vzniklo na Slovensku viacero významnejších múzeí. V prvom rade je potrebné spomenút, popri najväčších múzeách v Martine a Košiciach, najmä vytvorenie nového múzejného centra, ktoré sa začalo v 20. rokoch vytvárat’ v Bratislave. ${ }^{45}$ Bratislava sa po vzniku Československa stala hlavným mestom Slovenska. Symbolicky sa prejavil význam mesta nielen presunom najvyššieho správneho úradu na Slovensku, Ministra ČSR s plnou mocou pre správu Slovenska do Bratislavy, ale tiež založením súčasnej Univerzity Komenského. Pôsobilo tu od roku 1868 mestské múzeum, ku ktorému sa v prvej polovici 20. rokov pripojili d’alšie tri múzeá. Najskôr v roku 1922 vznikla v Bratislave pobočka pražského Zemědelského múzea, ktorá v roku 1924 začala s výstavbou novej účelovej budovy na nábreží Dunaja. Zemědelské múzeum bolo naviazané na agrárne politické hnutie, ktoré sa aj takýmto spôsobom angažovalo a propagovalo na Slovensku. ${ }^{46}$ Spoločne s ním tu začalo pôsobit aj Lesnícke múzeum, ktoré sa v roku 1927 spojilo so Zemedelským múzeom (ZM). Tretím novým múzeom sa stalo Slovenské vlastivedné múzeum (SVM), ktoré

44 ŠKULTÉTY, Jozef. Slovenské muzeum v Turčianskom Sv. Martine. In Sborník MSS, 1926, roč. 20, s. 60-63; ŠKULTÉTY, Jozef. Muzeálny obzor Slovenska. In Sborník MSS, 1926, roč. 20, s. 71

45 FALATHOVÁ, Zuzana. Múzejníctvo a výstavníctvo v Bratislave v období prvej Slovenskej republiky (1939-1945). Muzeológia a kultúrne dedičstvo, 2017, roč. 5, č. 2, s. 62.

46 RYCHLÍK, Jan. Zemědelská muzea v Československu. In HARNA, Josef a Blanka RAŠTICOVÁ (eds.). Agrární strana a její zájmové, družstevní a peněžní organizace. Uherské Hradiště: Slovácké muzeum v Uherském Hradišti, 2010, s. 207-208; STRELKOVÁ, Jarmila. Niekol'ko postrehov z počiatkov budovania Zemedelského múzea v Bratislave. In Zborník Slovenského národného múzea - História, 1996, roč. 36, s. $143-150$ vzniklo v roku 1924 a deklarovalo celoslovenskú pôsobnost', čím sa dostalo do vzájomného súperenia s martinským Múzeom. ${ }^{47}$

Napokon všetky tri múzeá začali pôsobit' v jednej účelovej budove, ktorá bola dostavaná v roku 1928 pre Zemedelské múzeum a od roku 1930 v nej sprístupnili svoje zbierky verejnosti. Došlo tak k vzájomnej spolupráci Zemedelské múzeum malo budovu s minimom zbierok, SVM zasa rozsiahle zbierky, pre umiestnenie ktorých hladalo vhodné priestory. Spomínané duplicitné zameranie SNM v T. Sv. Martine a SVM v Bratislave sa usiloval v roku 1930 vyriešit Krajinský výbor, ked' podporil snahy oboch inštitúcií o výstavbu vlastných budov - pod podmienkou, že sa dohodnú na rozdelení svojich kompetencií. SNM navrhovalo, aby sa bratislavské múzeum zameriavalo len na oblast' prírodných vied, s čím však SVM nesúhlasilo. Napokon sa v uzatvorenej dohode uzniesli, že „SNM je určené širokým vrstvám národa, SVM predne cielom vedeckým“. ${ }^{48} \mathrm{Z}$ oblasti výtvarného umenia sa SNM sústred’ovalo na zbieranie „pietnych národných pamiatok“, teda hlavne etnografických zbierok a predmetov osobností národného hnutia, kým SVM na diela „umeleckej galérie“ “, 49 teda prevažne umeleckohistorické zbierky. Najväčší spor vypukol v otázke, či má mat’ aj bratislavské SVM národopisný odbor. SVM argumentovalo hlavne tým, že Bratislava leží na hranici

\footnotetext{
47 Podrobne pozri prácu VALACHOVIČ, Pavol. Slovenské vlastivedné múzeum (1924-1939). In Zborník Slovenského národného múzea - História, 1984, roč. 24, s. 255-282 a STRELKOVÁ, Jarmila. Quo vadis, Slovenské národné múzeum? 2. Múzeum, 1997, roč. 42, č. 4, s. 5-11. Sprvu bola snaha umiestnit múzeum v Pálffyho paláci. NAČR, fond MŠA, kart. 3252, sign. č. 36439/25.

48 VALACHOVIČ, Pavol. Slovenské vlastivedné múzeum (1924-1939). In Zborník Slovenského národného múzea - História, 1984, roč. 24, s. $258-259$.

49 NAČR, fond MŠA, kart. č. 490. Slovenské vlastivedné múzeum.
} 
germánskeho, mad’arského a slovanského sveta, a preto je tu potrebné vybudovat vedecké národopisné centrum. Ďalším dôvodom bola výučba etnológie, resp. národopisu na Filozofickej fakulte UK, čo bez múzejných zbierok nebolo možné komplexne dosiahnut. SVM si tak zachovalo aj etnografický záber s celoslovenským zameraním, s užšou špecializáciou na západné Slovensko. ${ }^{50}$ Ministerstvo pravidelne upozorňovalo na duplicitné zameranie oboch múzeí a tým pádom nie vždy efektívne vynakladanie finančných prostriedkov a apelovalo na vyriešenie kompetencií oboch múzeí. ${ }^{51}$

Spomenuté múzeá rovnako stáli na spolkovom základe, dostávali štátne subvencie na činnost.. ${ }^{52}$ Okrem riadnych každoročných subvencií bola možnost' uchádzat sa aj o mimoriadne dotácie, ktoré sa týkali napríklad špeciálnych akvizícií. V roku 1937 takto SVM v Bratislave získalo až 30-tisícovú dotáciu na nákup pozostalosti po Alojzovi Kolískovi. Dotáciu schválil Krajinský úrad v Bratislave ako krajinskú dotáciu..$^{53}$ Tie sa ale dali získat aj od Štátneho referátu na ochranu pamiatok na Slovensku. ${ }^{54}$ Ked’že financie patrili k najväčším problémom slovenských múzeí, už pomerne skoro po vzniku Československej republiky vznikali myšlienky o možnom prechode múzeí pod verejnú správu. Vidina stáleho a stabilného rozpočtu, ktorý by umožňoval nielen kvalifikované personálne obsadenie pre rôzne činnosti

50 VALACHOVIČ, Pavol. Slovenské vlastivedné múzeum (1924-1939). In Zborník Slovenského národného múzea - História, 1984, roč. 24, s. 260.

51 NAČR, fond MŠA, kart. č. 490. Slovenské vlastivedné múzeum.

52 NAČR, fond $M \check{S} A$, kart. 3251, sign. č. $162794 / 31$.

53 NAČR, fond MŠA, kart. 3252, sign č. 246.459/6-1937

54 NAČR, fond MŠA, kart. 3252, sign. č.1757/36. spojené so zbierkami, ale zároveň aj možnoste určitého plánovania múzejných činností, znamenala pre mnohých zainteresovaných tú najlepšiu alternatívu d’alšieho rozvoja múzejníctva na Slovensku. Príkladom tohto snaženia bolo jedno z najstarších spolkových múzeí, Múzeum v Martine, neskoršie Slovenské národné múzeum v Martine, ${ }^{55}$ ktoré sa obrátilo so žiadostou o prevzatie do verejnej štátnej správy už na začiatku roku 1919. Výbor MSS požiadal 19. februára 1919 MŠANO o začlenenie martinského Múzea do krajinskej správy, čím by sa zabezpečila trvalá štátna subvencia na jeho činnost'. Napokon aj napriek vyhláseniu prezidenta T. G. Masaryka, ktorý delegáciu z Martina ubezpečil o svojej podpore, dostala MSS od Ministra ČSR s plnou mocou pre Slovensko zo 4. apríla 1919 vyrozumenie, $\mathrm{v}$ ktorom bolo poštátnenie múzea zamietnuté. Dôvodom bol nedostatok financií. S poštátnením museli slovenské múzeá počkat až do prelomu 40. a 50. rokov 20. storočia.

\section{Vznik špecializovaných múzeí}

Napriek vyššie spomenutým problémom sa $\mathrm{v}$ medzivojnovom období na Slovensku začala výrazne rozširovat a diverzifikovat múzejná siet. Novinkou bolo zakladanie špecializovaných múzeí. Najstarším bolo už spomínané Zemedelské, čiže pol'nohospodárske múzeum založené v roku 1922.

V Ohlase sa založenie „Slovenského polnohospodárskeho múzea $v$ Bratislave" prezentovalo ako „prvá kultúrna ustanovizeň slovenského rolníctva“, ktorého cielom je poznanie histórie slovenského rolníctva a jeho povznesenie aj do budúcnosti, lebo „poznat minulost',

55 RYBECKÝ, Milan. Muzeálna slovenská spoločnost́ a jej miesto v národnej kultúre. Martin: Osveta, 1983, s. 151-153. t. j. poznat' seba samých znamená: budovat' budúcnost."“56 Druhým špecializovaným a zároveň aj štátnym múzeom na Slovensku bolo Štátne banské múzeum Dionýza Štúra v Banskej Štiavnici založené v roku 1927.57 Ako vyplýva z názvu, sústred’ovalo sa na budovanie zbierok s banskou tematikou na území Slovenska i Podkarpatskej Rusi. Pamiatky spojené s banskou činnostou sa v Banskej Štiavnici zbierali ešte pred rokom 1918. ${ }^{58}$ Po vzniku ČSR sa opät rozvíjala myšlienka založenia špecializovaného múzea. Súčastou múzejnej činnosti bolo aj vykonávanie vedeckovýskumnej činnosti, hlavne v oblasti geológie, čo malo aj čiastočne kompenzovat pôsobenie zaniknutej akadémie. So založením múzea však nesúhlasilo Technické múzeum československé, ktoré začalo vyvíjat mimoriadne úsilie o získavanie pamiatok zo Slovenska a snažilo sa tak zamedzit realizácii tohto zámeru. Nenašlo však porozumenie v banských závodoch ani v nadriadenom ministerstve, ktorí tento zámer podporovali. Novozriadené banské múzeum D. Štúra malo dvojaké poslanie. Zhromažd’ovalo pamiatky súvisiace s baníctvom a takto názornými expozíciami demonštrovalo nerastné bohatstvo Slovenska a banskú tažbu na tomto území. Zároveň zabezpečovalo dokladový a porovnávací materiál z československých a cudzích ložísk a tiež malo prezentovat históriu baníctva a vývoj banskej

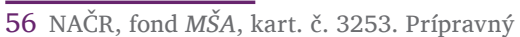
výbor Slovenského Polnnohospodárskeho Muzea: Ohlas! $2 \mathrm{~s}$, , nedatované. Štátny referát na ochranu pamiatok na Slovensku zaevidoval dokument 2. 2. 1923. Bratislava. Muzeum zemědělské.

57 Bližšie napríklad HERČKO, Ivan. Zberatel’ská činnost' z odboru baníctva a podnety pre založenie múzeí v Banskej Štiavnici (K 70. výročiu múzejníctva v Banskej Štiavnici). Múzeum, 1971, roč. 16, č. 1, s. 34-39. O činnosti múzea pravidelne informoval Časopis Muzeálnej slovenskej spoločnosti (1927, roč. 19, s. 64; 1931 , roč. 23 , s. 32; 1932, roč. 24 , s. 60-61).

58 Múzeum pôsobilo aj po vzniku ČsR. Bližšie napríklad: JURKOVIČ, Miloš. Slovenské múzeá. Bratislava: Slovenský fond výtvarných umení, 1945, s. 47-50. 
techniky v širšom meradle, poukázat na banícke spoločenstvo a sústredit všetky kultúrne, historické, technické, literárne a umelecké pamiatky viažuce sa k baníctvu a životu baníkov. Múzeum malo vystupovat aj ako vedeckovýskumný ústav, ktorý systematickým terénnym štúdiom, zberom a odborným petrografickogeologickým spracovaním materiálu realizuje geologický výskum hlavne v oblasti stredného Slovenska a jeho rudných ložísk.

V tomto období sa sformovalo aj špecializované prírodovedné múzeum zamerané na dokumentáciu slovenských jaskýň so sídlom v Liptovskom Svätom Mikuláši. Jeho počiatky však siahajú ešte do predvojnového obdobia. V roku 1904 na návrh Jána Volku-Starohorského (1880-1977), vtedy študenta prírodných vied na budapeštianskej univerzite, bola založená tzv. Liptovská zbierka, ktorej cielom bolo zbieranie liptovských prírodnín a „národných pamiatok“. Múzeum bolo oficiálne založené v roku 1928 ako Múzeum slovenského krasu ${ }^{59}$ a v roku 1930 boli jeho bohaté zbierky umiestnené a inštalované v priestoroch Župného domu.

Novým fenoménom

špecializovaných múzeí na Slovensku bol vznik cirkevných múzeí. Prešovské Židovské múzeum vzniklo v roku 1928 ako prvé svojho druhu na Slovensku. Najväčší podiel na jeho budovaní a zhromažd’ovaní zbierok mal predseda neologickej obce Eugen Bárkány a Teodor Austerlitz. ${ }^{60}$

59 Muzeum slovenského krasu v Liptovskom Sv. Mikuláši. Časopis MSS, 1931, roč. 23, s. 63; Pri Muzeu Slovenského krasu... Časopis MSS, 1932, roč. 24 , s. 92 . Dnes má múzeum názov Slovenské múzeum ochrany prírody a jaskyniarstva (SMOPAJ). JURKOVIČ, Miloš. Slovenské múzeá. Bratislava: Slovenský fond výtvarných umení, 1945, s. 88-90.

60 Dejiny múzea najkomplexnejšie spracovala Jana Švantnerová vo viacerých príspevkoch.
Následne na začiatku 30. rokov vznikli dve múzeá vd’aka podpore cirkevných inštitúcií: Diecézne (Diecezálne) múzeum v Spišskej Kapitule $^{61}$ (1932) a Múzeum Františka Richarda Osvalda ${ }^{62}$ pri Spolku sv. Vojtecha v Trnave (1934). Obe múzeá však mali zároveň aj silný regionálny záber, s výraznejším záberom na dokumentáciu trnavského a spišského regiónu. Nie všetky navrhované špecializované múzeá sa podarilo dotiahnut do úspešného konca. Pri desiatom výročí založení ČSR Obchodná a priemyselná komora v Bratislave navrhovala založit v Bratislave umelecko-priemyselné múzeum. Požiadala ministerstvo školstva, aby menovala dvoch zástupcov ako členov pripravovaného kuratória múzea. Zvolené kuratórium malo následne vypracovat stanovy múzea, tento projekt však nebol dotiahnutý do úspešného konca. ${ }^{63}$

\section{Regionálne múzeá}

Najvyšší počet múzeí na Slovensku tvorili mestské a regionálne múzeá, t. j. múzeá vlastivedného zamerania. Ich podrobnejšie priblíženie a činnost̉ je nad rámec rozsahu tohto príspevku a vyžadovalo by si osobitné spracovanie v samostatnej štúdii, preto spomenieme aspoň dve. Z múzeí regionálneho charakteru, ktoré vznikli pred rokom 1918, malo najvýznamnejšie postavenie štátne Východoslovenské

\section{Súhrnné informácie pozri: ŠVANTNEROVÁ Jana. Židovské múzeum v Prešove v širších súvislostiach. In BORSKÝ, Maroš a Jana ŠVANTNEROVÁ a kol. Eugen Bárkány. Medzi Prešovom a Bratislavou. Bratislava: Neinvestičný fond židovského kultúrneho dedičstva - Menorah,} 2018, s. 77 a n.

61 JURKOVIČ, Miloš. Slovenské múzeá. Bratislava: Slovenský fond výtvarných umení, 1945, s. 120-121.

62 JURKOVIČ, Miloš. Slovenské múzeá. Bratislava: Slovenský fond výtvarných umení, 1945, s. 130.

63 NAČR, fond MŠA, kart. č. 3253. Obchodná a priemyselná komora v Bratislave MŠA, Bratislava 26. 2. 1930; ŠIDLÍKOVÁ, Zuzana. Umeleckopriemyselné múzeum na Slovensku v roku 1928? Designum, 2010, č. 2, s. 14-17. múzeum (VM) v Košiciach. Jeho medzivojnová činnost je spojená s pôsobením riaditel'a Josefa Poláka. ${ }^{64} \mathrm{~K}$ najaktívnejším regionálnym múzeám v 20. rokoch patrilo Liptovské múzeum v Ružomberku. Kvôli narastaniu zbierok vedenie múzea, ako jediné z regionálnych múzeí, postavilo v medzivojnovom období, v rokoch 1935-1937, novú múzejnú budovu. ${ }^{65}$

Hoci niektoré z múzeí na Slovensku po vzniku Československa dočasne zanikli, konkrétne múzeá v Zlatých Moravciach a Šahách, ${ }^{66} \mathrm{v}$ priebehu 20. a 30. rokov vznikali nové. V 20. rokoch vzniklo dvanást’ múzeí. Okrem už spomínaných piatich múzeí (Zemedelské a Lesnícke múzeum a Slovenské vlastivedné múzeum v Bratislave, Štátne banské múzeum v Banskej Štiavnici a Židovské múzeum v Prešove) vznikli tiež d’alšie múzeá v Dolnom Kubíne, Kežmarku, Leviciach, Malackách, Prievidzi, Sabinove a Trenčianskych Tepliciach.

\footnotetext{
64 Bližšie o osobnosti J. Poláka pozri: VESELSKÁ, Magda. Muž, který si nedal pokoj: Př́iběh Josefa Poláka (1886-1945). Praha: Židovské muzeum v Praze, 2004. Spomeňme aspoň, že J. Polák o. i. zastával aj funkciu štátneho múzejného inšpektora. Východoslovenské múzeum v Košiciach sa už v medzivojnovom období angažovalo aj pri správe súkromných andrássyovských zbierok. Pozri TIŠLIAR, Pavol. Fate of the Andrássy Archive from Betliar and Krásna Hôrka in the 1940s and 1950s. Muzeológia a kultúrne dedičstvo, 2018, roč. 6, č. 2, s. 84.

65 Liptovské muzeum v Ružomberku. In Sborník MSS, 1926, roč. 20, s. 69-70; KÜRTI, Július. Pätnást' rokov Liptovského múzea. Ružomberok, 1927; Liptovské muzeum v Ružomberku. Časopis MSS, 1927, roč. 19, s. 35-38; KÜRTI, Július. Zpráva o účinkovaní Liptovského muzea v Ružomberku roku 1927. Časopis MSS, 1928, roč. 20, s. 103-104; Liptovské muzeum v Ružomberku. Časopis MSS, 1930, roč. 22, s. 30-31; KÜRTI, Július. 25-ročná jubilejná zpráva Liptovského muzea v Ružomberku. Ružomberok, 1937; JURKOVIČ, Miloš. Slovenské múzeá. Bratislava: Slovenský fond výtvarných umení, 1945, s. 114-115.

66 PALÁRIK, Miroslav. Zväz slovenských múzeí v období slovenského štátu 1939-1945. Nitra: Univerzita Konštantína Filozofa v Nitre, 2011, s. 18. Zbierky múzea v Zlatých Moravciach previezli v roku 1924 do Nitry a Šahách v roku 1923 do Banskej Štiavnice.
} 
Následne z 30. rokov máme správy o založení d’alších ôsmich múzeí (Bratislava - Hummelovo múzeum, ale ako expozícia mestského múzea, Gelnica, Nové Mesto nad Váhom, Nové Zámky, Pieštany, Prešov, Spišská Kapitula a Trnava). Ďalšie múzeá, ako Mestské múzeum v Žiline (1942) ${ }^{67}$ a Mestské múzeum vo Zvolene (1944), ${ }^{68}$ zasa vznikli začiatkom 40. rokov. Múzeá, ktoré vznikli v 30. rokoch, vznikli vd’aka priaznivému obdobiu 20. rokov.

\section{Záver}

Celkovo môžeme konštatovat', že v medzivojnovom období nastal rozmach slovenských múzeí. Ich počet sa za dvadsatročie existencie medzivojnového Československa takmer zdvojnásobil. Nemôžeme však hovorit o budovaní nejakej systematickej a koncepčnej múzejnej sieti na Slovensku koordinovanej štátnymi orgánmi, ked’že chýbala koncepčná stratégia, ktorá by definovala význam múzeí v rámci kultúrnej politiky štátu. Hlavným problémom bolo, že nebol prijatý múzejný zákon, ktorý by určil hlavné kritériá pri zakladaní múzeí, správe zbierok, ich ochrane a prezentácii verejnosti. Chýbala tiež systematická podpora pre finančné zabezpečenie chodu múzeí, vrátane podpory profesionalizácie pracovných pozícií. Pôsobenie Zväzu síce malo určitý pozitívny vplyv na vývoj slovenských múzeí, no tým, že jeho členmi bola len menšia čast̉ múzeí, tento vplyv nemal rozhodujúci charakter. Otázna je aj samotná

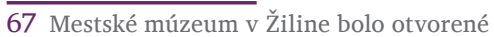
v roku 1942. Podnetom na založenie múzea bola drotárska výstava z roku 1940. Nachádzalo sa v budove bývalej radnice. JURKOVIČ, Miloš. Slovenské múzeá. Bratislava: Slovenský fond výtvarných umení, 1945, s. 142.

68 Mestské múzeum vo Zvolene: Podnetom na založenie múzea bola hospodársko-priemyselná výstava usporiadaná v roku 1921. Múzeum otvorili v roku 1944. Múzeum bolo umiestnené v provizórnych priestoroch na námestí, uvažovalo sa nad využitím Zvolenského zámku pre potreby múzea. JURKOVIC, Miloš. Slovenské múzeá. Bratislava: Slovenský fond výtvarných umení, 1945, s. 138. aktivita členských múzeí, ktorá sa javí skôr pasívna.

Verejnost’ o múzeá vel'ký záujem neprejavovala, a to ani politická reprezentácia, ani návštevnícka. Múzeá boli väčšinou odkázané na obetavú prácu dobrovol’ných pracovníkov, nadšencov združených v múzejných

\section{Až povojnové obdobie prinieslo} hlavný impulz k rozvoju slovenského múzejníctva v podobe postupného prechodu do verejnej správy, teda poštátnenia. ${ }^{69}$

\section{ZOZNAM PRAMEŇOV A LITERATÚRY}

Archiv Národního muzea v Prahe, fond Svaz československých muzeí.

Archív Pamiatkového úradu SR v Bratislave, fond Štátny inšpektorát archívov a knižníc na Slovensku.

Národní archiv České republiky v Prahe, fond Ministerstvo školství.

BOHUŠ, Ivan. Slovenské múzeá a prvá svetová vojna. Múzeum, 1958, roč. 5, č. 2, s. 76-77.

CIULISOVÁ, Ingrid. Osudy pamiatok na Slovensku 1919-1949. Poprad: KUBKO GORAL, 1994. ISBN 80-88858-04-6.

Časopis Muzeálnej slovenskej spoločnosti, 1927, roč. 19.

Časopis Muzeálnej slovenskej spoločnosti, 1931, roč. 23.

Časopis Muzeálnej slovenskej spoločnosti, 1932, roč. 24.

DVOŘÁK, Jan. Vývoj ideí a organisace ochrany památek. In PLACHT, Otto a František HAVELKA (eds.). Př́ručka školské a osvětové správy: Pro potřebu služby školských a osvětových úřadů a orgánů. Praha: Státní nakladatelství, 1934, s. 1612-1710.

FALATHOVÁ, Zuzana. Múzejníctvo a výstavníctvo v Bratislave v období prvej Slovenskej republiky (1939-1945).

69 Pozri napr. TAKÁCSOVÁ BÁNYÁSOVÁ, Katarína a Pavol TIŠLIAR. Vznik a formovanie Štátneho kultúrneho majetku v Betliari. Muzeológia a kultúrne dedičstvo, 2017, roč. 5, č. 1, s. $69-81$.
Muzeológia a kultúrne dedičstvo, 2017, roč. 5, č. 2, s. 61-76. ISSN 1339-2204.

FRAKNOI, Vilmos. Visszatekintés

A muzeumok és kónyvtárak országos tanácsa és fófelügyelősége egy évtized munkásságára (1898-1907). Budapest: Stephaneum Nyomda r.t., 1908.

HERČKO, Ivan a kol. Dejiny múzejnej kultúry na Slovensku. Banská Bystrica: Univerzita Mateja Bela, 2009.

ISBN 978-80-8083-931-4.

HERČKO, Ivan. Zberatel'ská činnost’ z odboru baníctva a podnety pre založenie múzeí v Banskej Štiavnici (K 70. výročiu múzejníctva v Banskej Štiavnici). Múzeum, 1971, roč. 16, č. 1, s. 39-43.

J. G. Sjazd československých muzeí v Bratislave. In ČMSS, 1930, roč. 22, s. $48-50$.

JURKOVIČ, Miloš. Slovenské múzeá. Bratislava: Slovenský fond výtvarných umení, 1945.

KAČÍREK, L’uboš. Edičná činnost̉ múzeí v druhej polovici 19. a prvej polovici 20. storočia. Muzeológia a kultúrne dedičstvo, 2017, roč. 5, č. 1, s. 43-56. ISSN 1339-2204.

KIRSCH, Otakar. (Po)zapomenutí nositelé paměti: Německé muzejnictví na Moravě. Brno: Paido, 2014. ISBN 978-80-7315-249-9.

KÜRTI, Július. 25-ročná jubilejná zpráva Liptovského muzea v Ružomberku. Ružomberok, 1937.

KÜRTI, Július. Pätnást' rokov Liptovského múzea. Ružomberok, 1927.

KÜRTI, Július. Zpráva o účinkovaní Liptovského muzea v Ružomberku roku 1927. Časopis MSS, 1928, roč. 20, s. 103-104.

LALKOVIČ, Marcel. Zväz československých múzeí a jeho prínos na formovaní slovenského múzejníctva. Zborník SNM Etnografia 44, 2003, s. 91-119.

Liptovské muzeum v Ružomberku. Časopis MSS, 1927, roč. 19, s. 35-38.

Liptovské muzeum v Ružomberku. Časopis MSS, 1930, roč. 22, s. 30-31.

Liptovské muzeum v Ružomberku. In Sborník MSS, 1926, roč. 20, s. 69-70. MRUŠKOVIČ, Štefan, Jolana DARULOVÁ a Štefan KOLLÁR. Múzejníctvo, muzeológia a kultúrne dedičstvo. Banská Bystrica: Univerzita Mateja Bela 
v Banskej Bystrici, 2005.

ISBN 80-8083-160-2.

Muzeum slovenského krasu v Liptovskom Sv. Mikuláši. Časopis MSS, 1931, roč. 23, s. 63.

NESVADBÍKOVÁ, Jiřina. $K$ vývoji památkové péče na území Československa. 3. svazek: Výběr autentických dokumentů 1918-1958. Praha: Státní pedagogické nakladatelství, 1983.

ORIŠKO, Štefan a Peter BUDAY. Pramene k umelecko-historickému bádaniu a ochrane pamiatok na Slovensku (1846-1918). Bratislava: Stimul, 2017. ISBN 978-80-8127-198-4.

PALÁRIK, Miroslav. Múzejná sieț na Slovensku v období I. Československej republiky - predstavy a realita. In HUPKO, Daniel a Luděk BENEŠ (eds.). Dokumentácia „osmičkových“ výročí $v$ slovenských a českých múzeách. Rok 1918 a tie ostatné. Banská Bystrica: Zväz múzeí na Slovensku, 2018, s. 84-126. ISBN 978-80-971748-7-3.

PALÁRIK, Miroslav. Zväz slovenských múzeí v období slovenského štátu 1939-1945. Nitra: Univerzita Konštantína Filozofa v Nitre, 2011. ISBN 978-80-8094-993-8.

Pri Muzeu Slovenského krasu... Časopis MSS, 1932, roč. 24, s. 92.

RYBECKÝ, Milan. Muzeálna slovenská spoločnost'a jej miesto v národnej kultúre. Martin: Osveta, 1983.

RYCHLÍK, Jan. Zemědelská muzea v Československu. In HARNA, Josef a Blanka RAŠTICOVÁ (eds.). Agrární strana a její zájmové, družstevní a peněžní organizace. Uherské Hradiště: Slovácké muzeum v Uherském Hradišti, 2010, s. 205-212. Studie Slováckeho muzea. 15/2010. ISBN 978-80-86185-90-3. Sbírka zákonů a nařizení republiky Československé, ročník 1918.

STRELKOVÁ, Jarmila. Niekol'ko postrehov z počiatkov budovania Zemedelského múzea v Bratislave. In Zborník Slovenského národného múzea - História, 1996, roč. 36, s. 143-150.

STRELKOVÁ, Jarmila. Quo vadis, Slovenské národné múzeum? 2. Múzeum, 1997, roč. 42, č. 4, s. 5-11.

ŠEBEK, František. Role Svazu československých muzeí ve vývoji českého (československého) muzejnictví. In HUPKO, Daniel a Luděk BENEŠ (eds.). Dokumentácia „osmičkových“ výroči $v$ slovenských a českých múzeách. Rok 1918 a tie ostatné. Banská Bystrica: Zväz múzeí na Slovensku, 2018, s. 128-144. ISBN 978-80-971748-7-3.

ŠIDLÍKOVÁ, Zuzana. Umeleckopriemyselné múzeum na Slovensku v roku 1928 ? Designum, 2010, č. 2, s. 14-17. ISSN 2644-5190.

ŠKULTÉTY, Jozef. Muzeálny obzor Slovenska. In Sborník MSS, 1926, roč. 20, s. 71-72.

ŠKULTÉTY, Jozef. Slovenské muzeum v Turčianskom Sv. Martine. In Sborník MSS, 1926, roč. 20, s. 60-63.

ŠVANTNEROVÁ, Jana. Židovské múzeum v Prešove v širších súvislostiach. In BORSKÝ, Maroš a Jana ŠVANTNEROVÁ a kol. Eugen Bárkány. Medzi Prešovom a Bratislavou. Bratislava: Neinvestičný fond židovského kultúrneho dedičstva Menorah, 2018, s. 76-105. ISBN 978-80-969720-8-1.

TAKÁCSOVÁ BÁNYÁSOVÁ, Katarína a Pavol TIŠLIAR. Vznik a formovanie Štátneho kultúrneho majetku v Betliari.
Muzeológia a kultúrne dedičstvo, 2017, roč. 5, č. 1, s. 69-81. ISSN 1339-2204. TIŠLIAR, Pavol. Fate of the Andrássy Archive from Betliar and Krásna Hôrka in the 1940s and 1950s. Muzeológia a kultúrne dedičstvo, 2018, roč. 6 , č. 2, s. 83-93. ISSN 1339-2204.

TIŠLIAR, Pavol, Jan DOLÁK a Luboš KAČÍREK. Changes in cultural strategy and cultural policies in Slovakia in the 20th century and at the beginning of the 21st century: museums and other memorial institutions in a socio-political context. Bylye gody, 2018, roč. 48, č. 2, s. 709-718. ISSN 2310-0028.

TIŠLIAR, Pavol. Formovanie ochrany pamiatok na Slovensku po vzniku Československej republiky. Vládny komisariát na ochranu pamiatok na Slovensku a Štátny inšpektorát archívov a knižníc na Slovensku. In GRESCHOVÁ, Eva. Stretnutie seniorov štátnej ochrany prírody na Slovensku. Liptovský Mikuláš: Slovenské múzeum ochrany prírody a jaskyniarstva, 2019, s. 5-19. ISBN 978-80-89933-17-4.

Uhorská krajinská zbierka zákonov z roku 1881.

VALACHOVIČ, Pavol. Slovenské vlastivedné múzeum (1924-1939). In Zborník Slovenského národného múzea - História, 1984 , roč. 24, s. 255-282.

VESELSKÁ, Magda. Muž, který si nedal pokoj: Př́́běh Josefa Poláka (1886-1945). Praha: Židovské muzeum v Praze, 2004. ISBN 80-86889-22-X.

Zákony a nariadenia na ochranu pamiatok historických, pravekých a prírodných na Slovensku. 3. vyd. Bratislava: Nákladom Štátneho referátu - tlačou Slovenskej kníhtlačiarne, 1924. 


\section{L'UBOŠ KAČ́́REK}

Katedra etnológie a muzeológie,

Filozofická fakulta, Univerzita Komenského

$\checkmark$ Bratislave,

Slovenská republika

Slovenské technické múzeum - Múzeum dopravy v Bratislave, Slovenská republika

lubos.kacirek@uniba.sk

lubos.kacirek@stm-ke.sk

L'uboš Kačírek vyštudoval odbor slovenský jazyk a literatúra - história a externé rozširujúce štúdium muzeológie na Filozofickej fakulte Univerzity Komenského v Bratislave, dizertačnú prácu v odbore slovenské dejiny obhájil v Historickom ústave Slovenskej akadémie vied v Bratislave.
Po ukončení magisterského štúdia pracoval v Múzeu mesta Bratislavy, neskôr na Katedre histórie

Pedagogickej fakulty UK v Bratislave. Od roku 2008 pôsobí na Katedre etnológie a muzeológie FiF UK v Bratislave. Zároveň od roku 2019 je riaditel’om Slovenského technického múzea - Múzea dopravy v Bratislave. Venuje sa slovenským dejinám v 19. a 20. storočí, osobitne dejinám múzejníctva a kultúrnemu dedičstvu $\mathrm{v}$ širšom kontexte.

L'uboš Kačírek completed the study of Slovak Language and Literature History and an external course in museology at the Faculty of Arts of the Comenius University in Bratislava. He defended his dissertation on Slovak history at the Institute of History of the Slovak Academy of Sciences in Bratislava. After graduation he worked in the Bratislava City Museum, and later at the Department of History of the Faculty of Education of the Comenius University in Bratislava. Since 2008 he has been working at the Department of Ethnology and Museology of the Faculty of Arts, Comenius University in Bratislava. Since 2019 he also is Director of the Slovak Technical Museum Museum of Transport in Bratislava. He specialises in the 19th and 20th century Slovak history, focusing on the history of museology and cultural heritage in a broad context.

\section{PAVOL TIŠLIAR}

Katedra etnológie a muzeológie, Filozofická fakulta,

Univerzita Komenského v Bratislave,

Slovenská republika

Ústav archeologie a muzeologie, Filozofická fakulta

Masarykova univerzita, Brno,

Česká republika

pavol.tisliar@uniba.sk

tisliar@phil.muni.cz
Pavol Tišliar je profesorom

slovenských dejín. Pôsobí na Ústave archeologie a muzeologie Filozofickej fakulty Masarykovej univerzity v Brne a na Katedre etnológie a muzeológie Filozofickej fakulty Univerzity Komenského v Bratislave. Publikuje z oblasti dejín múzejníctva a monumentológie, teoretických problémov kultúrneho dedičstva a ako historik aj v oblasti socialnokultúrnych dejín Slovenska.
Pavol Tišliar is professor of Slovak history. He works at the Department of Archeology and Museology at the Faculty of Arts, Masaryk University in Brno and at the Department of Ethnology and Museology at the Faculty of Arts, Charles University in Bratislava. He publishes the history of museums (museology) and monumentology, theoretical problems of cultural heritage and as a historian also in the field of socio-cultural history of Slovakia. 